\title{
Socioeconomic Development of Regions of Siberia and Russian Far East: Statistical Analysis
}

\author{
Dashi Dashanimaevich Tsyrenov ${ }^{1 *}$ \\ ${ }^{1}$ Buryat State University, Smolin St., 24a, Ulan-Ude, 670000, Russia \\ *Corresponding authorE-mail: dashi_tsyrenov@bk.ru
}

\begin{abstract}
The economic development of Russia, given the country's vast territory, the distribution patterns of natural resources and population, and the diverse climate conditions, is logically uneven and characterized by territorial variation. Particular focus of the federal government should be placed on the conditions emerging in Siberia and the Russian Far East. The major limiting factor is the increasing population outflows to the central federal subjects of the Russian Federation, particularly visible among the working-age population. Apart from it, another limiting factor is the natural conditions in these two federal districts, namely, the harsh weather conditions, the typical inland climate, seismic activity, etc. Moreover, a major part of Siberia and the Far East is designated as a territory with special requirements in terms of natural resource development, which is due to the existing national reserves and parks. The Baikal natural area, the basin of Lake Baikal, are of particular importance. These factors have brought to the foreground the need for a break-up of the Siberia Federal District and the Far East Federal District to improve the economic efficiency of such spacious areas of the country. There is a proposal to establish a new federal district known under the working reference as "Central Eurasia" and meant to include the Republics of Buryatia, Tyva, Khakassia, and Sakha (Yakutia), the Trans-Baikal and Krasnoyarsk Territories and the Irkutsk region. The proposed spatial arrangement of productive forces would improve the efficiency of use of both labor and natural resources.
\end{abstract}

Keywords: Federal District, Spatial Arrangement, Siberia, Far East, Eurasian Territory, Interregional Cooperation.

The regions of Siberia and the Russian Far East face similar blocks of problems in their social and economic development:

- $\quad$ vast territory, low population density, fragmentation of economic space;

- concentration of natural resources in distant and not easily accessible areas;

- increased costs of establishing and maintaining all types of infrastructure and high costs of cargo and passenger transit;

- considerable spending on sustaining the local life patterns;

- considerable polarization in income levels and living standards.

Better efficiency and quality of governance can be achieved by demerging several regions from the Siberia Federal District and the Far East Federal District to make up a new federal district, the Central Eurasia district. The political rationale behind such governance decision relates to the shifts in the global trends toward the Eastern and Asian continent, on the one hand, and the shift in the development of productive forces in Russia toward East Siberia and the Western Far East, on the other hand. The Central Eurasia Federal District would comprise the Republics of Buryatia,
Tyva, Khakassia, and Sakha (Yakutia), the Trans-Baikal and Krasnoyarsk Territories and the Irkutsk region.

The main exogenous factor behind the lagging performance of Siberian and Far Eastern regions is the lack of alignment between the country's existing administrative and economic zone arrangements [1]. For instance, the entities of the Baikal microregion (the Irkutsk region, the Republic of Buryatia and the Trans-Baikal Territory) belong to the eastern zone of the Siberia Federal District. Meanwhile, the program-based governance designates them as the Far East Federal District, its western zone. Such uncertain position of the Baikal microregion leads to the emergence of the so-called "desert territory" where all governance procedures are implemented "on a leftover principle".

In terms of area, just three subjects of the Baikal microregion spanning 1,558 thousand sq. $\mathrm{km}$ are well ahead of the Central Federal District (650 thousand sq. km), the Southern Federal District (447 thousand sq. km), the North Caucasus Federal District (170 thousand sq. km) and the Volga Federal District (1,037 thousand sq. km) $[2,3,4]$. The vast territory of the Inner Asia, which is the center of the Eurasian space, is overlooked in strategic planning and programming in the Russian Federation (Table 1).

Table 1: Major indicators of the level of development in the Federal Districts of Russia

\begin{tabular}{|c|c|c|c|c|c|c|c|c|c|c|c|c|c|c|c|}
\hline \multirow[b]{2}{*}{$\begin{array}{l}\text { Federal } \\
\text { Districts }\end{array}$} & \multicolumn{3}{|c|}{ Area } & \multicolumn{3}{|c|}{ Population } & \multicolumn{3}{|c|}{ GRP } & \multicolumn{3}{|c|}{ Production Capital Stock } & \multicolumn{3}{|c|}{ Investment } \\
\hline & $\begin{array}{c}\text { thousand. } \\
\text { sq.km }\end{array}$ & $\begin{array}{c}\text { as percent- } \\
\text { age of RF } \\
\text { total }\end{array}$ & rank & $\begin{array}{c}\text { thousand } \\
\text { people }\end{array}$ & \begin{tabular}{|c|} 
as percent- \\
age of \\
RF total
\end{tabular} & rank & $\begin{array}{l}\text { million } \\
\text { rubles }\end{array}$ & $\begin{array}{c}\text { as percent- } \\
\text { age of } R F \\
\text { total }\end{array}$ & rank & $\begin{array}{l}\text { million } \\
\text { rubles }\end{array}$ & \begin{tabular}{|c|} 
as percent- \\
age of \\
RF total
\end{tabular} & rank & $\begin{array}{l}\text { million } \\
\text { rubles }\end{array}$ & \begin{tabular}{|c|} 
as percent- \\
age of \\
RF total
\end{tabular} & rank \\
\hline $\begin{array}{l}\text { Central } \\
\text { Federal District }\end{array}$ & 650.2 & 3.80 & 7 & 39,209 & 26.71 & 1 & $22,713,911.1$ & 34.95 & 1 & $58,400,591$ & 31.84 & 1 & $3,795,986$ & 26.00 & 1 \\
\hline \begin{tabular}{|l|} 
Northwest \\
Federal District
\end{tabular} & 1,687 & 9.85 & 4 & 13,899 & 9.47 & 4 & $6,790,148.1$ & 10.45 & 4 & $20,330,095$ & 11.08 & 4 & $1,660,840$ & 11.37 & 4 \\
\hline Southern & 447.8 & 2.61 & 8 & 16,429 & 11.19 & 3 & $4,590,595$ & 7.06 & 5 & $14,201,426$ & 7.74 & 5 & $1,110,446$ & 7.60 & 5 \\
\hline
\end{tabular}




\begin{tabular}{|c|c|c|c|c|c|c|c|c|c|c|c|c|c|c|c|}
\hline Federal District & & & & & & & & & & & & & & & \\
\hline $\begin{array}{l}\text { North Caucasus } \\
\text { Federal District }\end{array}$ & 170.4 & 1.00 & 9 & 9,776 & 6.66 & 7 & $1,704,330.8$ & 2.62 & 9 & $4,515,820$ & 2.46 & 9 & 484,958 & 3.32 & 9 \\
\hline $\begin{array}{l}\text { Volga } \\
\text { Federal District }\end{array}$ & 1037 & 6.06 & 5 & 29,637 & 20.19 & 2 & $9,916,064.2$ & 15.26 & 2 & $25,329,929$ & 13.81 & 3 & $2,429,023$ & 16.63 & 3 \\
\hline $\begin{array}{l}\text { Urals } \\
\text { Federal District }\end{array}$ & $1,818.5$ & 10.62 & 3 & 12,345 & 8.41 & 5 & $8,980,445.7$ & 13.82 & 3 & $33,650,787$ & 18.35 & 2 & $2,730,971$ & 18.70 & 8 \\
\hline $\begin{array}{l}\text { Siberia } \\
\text { Federal District } \\
\text { * }\end{array}$ & 990 & 5.78 & 6 & 11,124 & 7.58 & 6 & $3,448,262.6$ & 5.31 & 7 & $7,539,387$ & 4.11 & 8 & 577,635 & 3.96 & 8 \\
\hline $\begin{array}{l}\text { Far East Federal } \\
\text { District } * *\end{array}$ & $3,085.8$ & 18.02 & 2 & 5,220 & 3.56 & 9 & $2,799,631$ & 4.31 & 8 & $9,611,850$ & 5.24 & 7 & 709,884 & 4.86 & 7 \\
\hline $\begin{array}{l}\text { Central Eura- } \\
\text { sia Federal } \\
\text { District } * * *\end{array}$ & $7,238.5$ & 42.27 & 1 & 9,165 & 6.24 & 8 & $4,053,650.8$ & 6.24 & 6 & $9,823,808$ & 5.36 & 6 & $1,102,976$ & 7.55 & 6 \\
\hline Total: & $1,7125.2$ & 100.00 & & 146,804 & 100.00 & & $64,997,039.3$ & 100.00 & & $183,403,693$ & 100.00 & & $14,602,719$ & 100.00 & \\
\hline
\end{tabular}

* The Siberia Federal District is shown exclusive of the Republics of Buryatia, Tyva, Khakassia, the Trans-Baikal and Krasnoyarsk Territories, and the Irkutsk region.

** The Far East Federal District is shown exclusive of the Republic of Sakha (Yakutia)

*** The Republics of Buryatia, Tyva, Khakassia, Sakha (Yakutia), the Trans-Baikal and Krasnoyarsk Territories, and the Irkutsk region are included

The establishing of a new federal district comprising the Republics of Buryatia, Tyva, Khakassia, and Sakha (Yakutia), the TransBaikal and Krasnoyarsk Territories and the Irkutsk region is primarily due to the natural and historical prerequisites. For example, the said regions have a common basin divide, namely, Lake Baikal with numerous rivers falling into it, - the Angara - the Yenisey the Arctic ocean to the west - and the Lena - the Arctic ocean to the east. The regions to be merged make the hydropower base of Russia. They are the richest subjects of the Russian Federation by the levels of mineral resources, hydrocarbons and forestry.

The development of the Northern Sea Route will put the Central Eurasia Federal District in a position to actively harness its geostrategic and geopolitical position as a major Russian link to the countries of the Southeast Asia (via Mongolia and China) [5, 6]. The described regions lie at the intersection of the "vertical" (the Arctic - South East Asia) and "horizontal" (east to west) links, which also makes the case for the need to establish a new federal district. The Central Eurasia Federal District is the ancestral original homeland for many peoples and ethnic groups (the Huns, the Turkis, the Buryat-Mongols, etc.).
The regions to make up the Central Eurasia Federal District are deservedly called the global natural health resort, with its balneological destinations, medical herbs, ozone therapy and many other things. A particular interest lies in the developed practices of ethnomedicine.

Conditions are in place in these subjects of the Russian Federation for the development of ethnoeconomy and aqua economy [7]. Ethnoeconomy refers to economic arrangements based on the ethnically and historically driven principles of public economy. Aqua economy enables more efficient use of water, a major resource of the 21 st century.

The new federal district will fill a niche of its own in the existing structure of federal districts, commanding the first place in terms of area, eighth, in terms of population, sixth, in terms of the gross regional product, production capital stock and investment (Table 1).

Within the new district structure, the leading ground will be taken by the Krasnoyarsk Territory and the Irkutsk region (Table 2).

Table 2: Socioeconomic indicators of the entities of the Central Eurasia Federal District

\begin{tabular}{|l|c|c|c|c|c|c|c|c|c|c|}
\hline $\begin{array}{l}\text { Federal Sub- } \\
\text { jects } \\
\text { of the RF }\end{array}$ & \multicolumn{2}{|c|}{ Area } & \multicolumn{2}{c|}{ Population } & \multicolumn{2}{c|}{ GRP } & \multicolumn{2}{c|}{ Production Capital Stock } & \multicolumn{2}{c|}{ Investment } \\
\hline $\begin{array}{l}\text { thousand } \\
\text { sq. km }\end{array}$ & $\begin{array}{c}\text { as percentage } \\
\text { of RF total }\end{array}$ & $\begin{array}{c}\text { thousand } \\
\text { people }\end{array}$ & $\begin{array}{c}\text { as percentage } \\
\text { of RF total }\end{array}$ & $\begin{array}{c}\text { million } \\
\text { rubles }\end{array}$ & $\begin{array}{c}\text { as percentage } \\
\text { of RF total }\end{array}$ & $\begin{array}{c}\text { million } \\
\text { rubles }\end{array}$ & $\begin{array}{c}\text { as percentage } \\
\text { of RF total }\end{array}$ & $\begin{array}{c}\text { million } \\
\text { rubles }\end{array}$ & $\begin{array}{c}\text { as percentage } \\
\text { of RF total }\end{array}$ \\
\hline $\begin{array}{l}\text { Trans-Baikal } \\
\text { Territory }\end{array}$ & 451.3 & 2.05 & 984 & 0.67 & $204,156.2$ & 0.31 & 609,133 & 0.33 & 30,812 & 0.21 \\
\hline Irkutsk region & 774.8 & 4.52 & 2,409 & 1.64 & $1,013,542.3$ & 1.56 & $2,528,848$ & 1.38 & 258,493 & 1.77 \\
\hline $\begin{array}{l}\text { Krasnoyarsk } \\
\text { Territory }\end{array}$ & $2,366.8$ & 13.82 & 2,875 & 1.96 & $1,618,166$ & 2.49 & $3,227,379$ & 1.76 & 419,060 & 2.87 \\
\hline $\begin{array}{l}\text { Republic of } \\
\text { Tyva }\end{array}$ & 168.6 & 0.98 & 318 & 0.22 & $47,287.3$ & 0.07 & 91,880 & 0.05 & 8,556 & 0.06 \\
\hline $\begin{array}{l}\text { Republic } \\
\text { of Khakassia }\end{array}$ & 61.6 & 0.36 & 537 & 0.37 & $171,663.9$ & 0.26 & 417,845 & 0.23 & 26,766 & 0.18 \\
\hline $\begin{array}{l}\text { Republic of } \\
\text { Sakha (Yaku- } \\
\text { tia) }\end{array}$ & $3,083.5$ & 18.01 & 963 & 0.66 & $749,987.5$ & 1.15 & $2,025,084$ & 1.10 & 275,273 & 1.89 \\
\hline Total: & $7,238.5$ & 42.27 & 9,165 & 6.24 & $4,053,650.8$ & 6.24 & $9,823,808$ & 5.36 & $1,102,976$ & 7.55 \\
\hline
\end{tabular}

\section{Acknowledgement}

The research presented in this paper forms a fundamental part of the implementation of a 2018 government assignment from the Ministry of Education and Science of the Russian Federation, 'Boosting the Efficiency of the Spatial Organization of the Regions of Siberia and the Far East in a Climate of Demographic and Environmental Challenges' (26.5756.2017/BCh).

\section{References}

[1] Chimitdorgieva E.Ts., Aydaev G.A., Tsyrenov D.D., Balkhanov A.M., Malishev E.A. (2016) Assessment of the Nature of Reproduction Processes in Rural Municipalities (districts) of the 
[2] Region of Buryatia. International Review of Management and Marketing, 6(S3), pp. 239-245

[3] Slepneva L.R., Tsyrenov D.D., Kokorina A.A., Slepneva J.V., Munkueva I.S. (2016) Socio-economic Development of Regions of Russia: Assessment of the State and Directions of Improvement. International Journal of Economics and Financial Issues, 6(S2), pp. 179-187.

[4] Tsyrenov D.D., Munkueva I.S., Dondokova E.B., Sharaldaev B.B., Goryunova L.A. (2015) Statistical Research on Spatial Differentiation of the Innovation System of the Russian Federation. Journal of Applied Economic Sciences (ISSN18436110-Romania-Scopus), Volume X, Issue 5(35)/6(36).

[5] Mikhailova S.S., Moshkin N.I., Tsyrenov D.D., Sadykova E.Ts., Dagbaeva S.D-N. (2017) A Spatial Analysis of Unevenness in the Social-Economic Development of Regional Municipal Units. ERSJ - European Research Studies Journal (ISSN1108-2976, Scopus, Greece), Volume XX, Issue 2B, pp. 46-65

[6] Avramchikova N.T., Chuvashova M.N. Avramchikova N.T., Chuvashova M.N. (2014) Problemy povysheniya kachestva ekonomicheskogo prostranstva $\mathrm{v}$ resursno-orientirovannykh regionakh Rossiiskoi Federatsii [Issues of Economic Space Quality Improvement in Resourse-Dependent Regions of the Russian Federation]. Regional'naya ekonomika: teoriya i praktika [Regional Economy: Theory and Practice], No. 5 (332), pp. 3-11

[7] Belskikh I.E. (2014) Regional'nye brendy: spetsifika razvitiya Rossii [Regional Brands: Aspects of Development of Russia]. Regional'naya ekonomika: teoriya i praktika [Regional Economy: Theory and Practice], No. 26 (353), pp. 3-7.

[8] Kistanov V.V. (2007) Obiedinenie regionov Rossii [Merging of Russian Regions]. Moscow: Ekonomika, 139 p. 